\title{
1. Introduction to the institution of the company share
}

\subsection{THE SHARE AS A FEATURE OF MODERN LIFE}

Shares have become part of the architecture of modern life, almost to the extent that they now possess a degree of invisibility because of their ubiquity. Over the past 300 years shares and the dealings in shares of limited liability companies have featured occasionally as part of a literary plot, ${ }^{1}$ in film scripts ${ }^{2}$ and even in an opera. ${ }^{3}$ For many years share price listings have been a staple part of the quality newspapers' daily publication output. There are specialist publications geared exclusively towards the investor audience. ${ }^{4}$ We all ${ }^{5}$ now accept the idea of a person holding a share in a limited company, and for that reason it has become passé,

1 The best example is to be found in Anthony Trollope's, The Way We Live Now (1875) (Chapman \& Hall), where a dubious share issue in an overseas railway venture forms part of the literary plot (see Ch IX). See also D. Liss, $A$ Conspiracy of Paper (2000) (Random House) which deals with fictional matters related to the South Sea Company.

2 So for instance Wall Street (1987), Boiler Room (2000) and The Wolf of Wall Street (2013).

3 W.S. Gilbert and A. Sullivan, Utopia Ltd (or The Flowers of Progress) (1893). It is more of a satire on limited liability rather than the use of the share itself. The author is not aware of the share or share dealing being widely used as the subject of a work of fine art. Perhaps E.M. Ward's 1846 portrayal of The South Sea Bubble in the Hogarthian style is the best example. There is also Jan Breughel the Younger's 1640 satire on human folly in the context of 'tulipmania' (see Ch 2 below) as a further manifestation of this subject providing inspiration in art. The Dutch etching (c. 1720) The Night Singer with his Magic Lantern should also be noted.

4 The Investors' Chronicle can trace its ancestry back to 1860.

5 Sharia Law accepts the concept of a share provided the company issuing the securities is not engaged in activities deemed unacceptable to Islam (haraam). These would be companies loaning money for interest (riba) or dealing in prohibited goods/services (e.g. alcohol). Many jurisdictions in non-Moslem countries have gone to great lengths to attracting the Islamic investor by establishing Sharia-compliant indices or markets. 
operating at close to a subliminal level. It is only when there is a high-profile privatisation share issue designed to attract first-time investors to the shareholding game, or the shock of a sudden general market crash, or a high-profile corporate failure, ${ }^{6}$ that questions such as share prices and investor protection become a matter of everyday discourse. Although recent media discussion of the transparency problems posed by allowing beneficial share ownership has been prominent in policy circles, the media, and among corporate practitioners, one suspects that the full implications of the responsive reform initiated by government through the Small Business, Enterprise and Employment Act 2015 will have gone over the heads of the wider public audience.

In terms of calculating the magnitude of personal wealth, shares often play a more significant role than cash holdings. Increasingly, personal shareholdings also outweigh an individual's worth in terms of real property holdings. Variations in share prices can however lead to sharp fluctuations in one's ranking position in the various published wealth lists. ${ }^{7}$ Shares are risk capital in the proper sense of the term.

Shares may have an intrinsic value that goes beyond their obvious economic value. A worthless share in a defunct enterprise which is represented by a share certificate in good condition may in the future become a valuable collectors' item. The hobby of scripophily is now well established, with rare share certificates being purchased for tens of thousands of pounds. ${ }^{8}$ With the inexorable trend towards dematerialised shares, the scarcity and value of old paper shares will be likely to grow.

6 The collapse in the USA of Enron in December 2001 triggered much debate, media interest, an SEC investigation and ultimately legislative reform which was aimed at protecting investors - the Sarbanes Oxley Act of the US Congress in 2002. For discussion see D. Campbell and S. Griffin, 'Enron and the End of Corporate Governance' in S. McLeod (ed), Global Governance and the Quest for Justice (2006) (Hart Publishing) at 47, J.A. McCahery and J. Armour in After Enron: Improving Corporate Law and Modernising Securities Regulation in Europe and the US (2006) (Hart). The Enron 'bubble', its collapse and the legislative reaction have often been compared to events taking place in England in 1720.

7 The Sunday Times Rich List (published since 1989) includes the value of shareholdings when calculating the wealth of UK residents.

8 For a flavour of the hobby of collecting old share certificates see K. Hollender, Scripophily: Collecting Bonds and Share Certificates (1982) (Littlehampton Book Services). 


\subsection{WHAT IS A SHARE?}

As Professor Robert Pennington explained ${ }^{10}$ some 30 years ago, we have been slow to develop a proper understanding of the nature of a share in a registered company. We have formed a picture based upon jurisprudence tied up with earlier manifestations of the modern company; such as the chartered company and unincorporated joint stock associations. Moving to the role of the share in modern companies we can reaffirm that at its heart a share is a risk minimisation device individuals with surplus capital may invest some of their funds in a potentially profitable/potentially risky business venture in such a way as to cap their losses if the project fails. The share is the most popular legal device that facilitates this form of financial alchemy. It is no exaggeration to say that it is central to the workings of the whole edifice of capitalism. This is not the only method of capping liability. A guarantee of a portion of a company's debts can be used. ${ }^{11}$ But companies limited by guarantee have not proved popular in this context. Although recognised by the Companies Act 2006 (ss. 3 and 5), they are now used exclusively in the charitable environment.

By exchanging cash (or the equivalent non-cash consideration) for a share, a person who buys a share acquires a bundle of economic rights underpinned by the law. ${ }^{12}$ The classic legal explanation of the resultant

9 A related question, which is relevant for entrepreneur tax relief purposes, is what is 'ordinary share capital'? This issue has been examined by the Upper Tribunal in McQuillan v HMRC [2017] UKUT 0344 (TCC) where it was decided that a class of share with no dividend rights could not be regarded as offering a fixed rate of dividend; therefore the class was properly to be regarded as ordinary share capital within the meaning of s. 989 of the Income Taxes Act 2007.

10 See (1989) 10 Co Law 140. But valuable insights may be gleaned from S. Worthington (2001) 22 Co Law 258 and 307. See also D.G. Rice [1957] 21 Conv (NS) 433. B. Sheehy (2006) 6 JCLS 165 at 191 et seq.

11 See Companies Act 2006 s. 3(3). But a company cannot limit liability of members by combining share capital with guarantees - ibid s. 5 .

12 The analysis that follows does not apply to interests held in charitable companies limited by guarantee. A member cannot be said to have an economic interest in such companies - per Vos $\mathrm{C}$ in The Children's Investment Fund Foundation (UK) v HM Attorney General [2017] EWHC 1379 (Ch) para [46] reversed on other grounds - [2018] EWCA Civ 1605. 
package was provided by Farwell J in Borland's Trustee $v$ Steel Bros. ${ }^{13} \mathrm{It}$ goes as follows:

A share is the interest of a shareholder in the company measured by a sum of money, for the purpose of liability in the first place, and of interest in the second, but also consisting of a series of mutual covenants entered into by all of the shareholders inter se ...

This stresses the link with the so-called 'statutory contract' now embodied by s. 33 of the Companies Act 2006. ${ }^{14}$

Moving forward in time, Lord Millett in Johnson v Gore Wood \& Co ${ }^{15}$ proffered this analysis:

... although a share is an identifiable piece of property which belongs to the shareholder and has an ascertainable value, it also represents a proportion of the Company's net assets, and if these are depleted the diminution in its assets will be reflected in the diminution in the value of the shares.

Looking further afield for judicial enlightenment, Keane $\mathrm{J}$ proffered this explanation in the High Court in Ireland in Re Sugar Distributors Ltd ${ }^{16}$ :

A share in a company is, in effect, a bundle of proprietary rights which can be sold or exchanged for money or other valuable consideration.

Reverting to the UK position, the Companies Act 2006 has in the provisions of s. 540 finally got round to providing a statutory definition of a share. ${ }^{17} \mathrm{~A}$ share is a share in the company's share capital. That definition admittedly is of limited use, but, after 150 years of waiting, we should regard this as a form of belated and limited enlightenment. In

13 [1901] 1 Ch 279 at 288. Followed by Lord Russell of Killowen in IRC $v$ Crossman [1937] AC 26 at 66. See also Commissioners of the Inland Revenue $v$ Laird Group [2003] UKHL 54 at para [35] per Lord Millett.

14 This legalistic perspective is reinforced by the comments of Briggs LJ in Blackwell v HMRC [2017] EWCA Civ 232 at paras [21]-[22] - when assessing for capital gains tax purposes the package of rights/obligations attached to a share, any personal undertakings given by a shareholder (e.g. as to disposal of the shares) are not strictly to be taken into account.

15 [2002] 2 AC 1 at 62. Further discussion of the modern perspective on shares is provided by Hildyard $\mathrm{J}$ in Lomas $v$ Burlington Loan [2016] EWHC 2417 (Ch) at paras [86] and [137]. See also Sydney Futures Exchange $v$ Australian Stock Exchange (1995) 13 ACLC 369 at 384 per Lockhart J.

16 [1995] 2 IR 194 at 207.

17 Note also art 1 of The Companies (Model Articles) Regulations 2008 (SI 2008/3229). 
particular, it is helpful to understand that a share does not give a shareholder a direct claim to company assets. In technical terms a share is a chose in action. It is also a 'financial instrument' for the purposes of the EU measure known as MiFID. ${ }^{18}$

One point must be clarified. Acquiring a share in a company as a general rule offers no guarantees to the shareholder about future income or even having a proportionate interest in the company's assets. The economic interest of a shareholder can, as a general rule, ${ }^{19}$ quite legitimately be diluted by the company increasing its share capital. The advent of formal pre-emption rights (discussed in Chapter 5 below) on new share issues mitigates this problem to some extent, but the risk of dilution has not gone away completely. Other perils to the value of one's shareholding should also be borne in mind. The nature of the company in which the shareholder invested may change; it may switch from a public company to a private company. ${ }^{20}$ It may be taken over or it may merge. It may go into liquidation. A shareholder does not have an absolute personal right to see that the value of his/her shareholding is maintained. If the company becomes insolvent the rights of a shareholder largely disappear. $^{21}$

Another important qualification to reiterate at this stage is that owning a share (or indeed all of the shares) in a company does not confer direct ownership rights over company assets. ${ }^{22}$ Thus, a controlling shareholder

18 Market in Financial Instruments Directive 2004/39/EC. There is now a MiFID II (2014/65) and a MiFIR (600/2014).

19 But the courts might intervene where there is some evidence of unfairness - see Clemens v Clemens Bros Ltd [1976] 2 All ER 268.

20 See Companies Act 2006 s. 97. In this scenario the holders of 5\% of the shares can apply to the court to challenge this transition - see s. 98. For a failed application under s. 98 see Re D'Nick Holdings plc (Eckerle v Wickeder Westfalenstahl) [2013] 3 WLR 1316. Here the court struck out the s. 98 application primarily because the applicants, who were indirect investors in the companies' securities, could not in the opinion of Norris J be viewed as 'holders' of shares for the purposes of s. 98 .

21 On the circumstances where the right to bring a derivative claim is lost see Fargro v Godfroy [1986] BCLC 370 and the discussion by A. Keay [2008] 21 Ins Intell 49. For a Singaporean authority to the same effect see Petroships Investment Pte Ltd $v$ Wealth Plus Pte Ltd [2016] SGCA 17.

22 See here the comments of Lord Wrenbury in Bradbury $v$ English Sewing Cotton Co Ltd [1923] AC 744 at 767 stressing that the shareholder has property rights in the share but not in the company's assets. In a sense a shareholding, particularly a majority shareholding, may in loose terms create indirect property rights. A modern statement of principle is provided by Zacaroli $\mathrm{J}$ in Raffermati $v$ Capello Hair Designs Ltd [2017] EWHC 3134 (Ch) at para [40]. For an 
has no insurable interest in the company's assets. ${ }^{23}$ Nor does such a shareholder have the right to appropriate the company's assets. ${ }^{24}$ Most recently, the Court of Appeal has confirmed that a freezing order over the assets of a defendant (who happens to own all of the shares in a company) does not extend to the assets of said company. ${ }^{25}$ The distinct legal identities of company and shareholder, so essential to the idea of limited liability, must be respected.

\subsection{WHO OWNS SHARES?26}

Having explained the rudimentary features of a share we now need to consider who uses this legal device. It is clear that there are many millions of shareholders in the UK. These shareholders own a greater number of the millions of shares in circulation in this country. If we multiply that figure to reflect the world investor community, we are looking at a significant global population of investors and shares.

The share has played its part in the phenomenon known as 'globalisation' by encouraging capital flows across national borders, and by giving the foreign investor a real stake in a selection of national economies.

The Office for National Statistics (ONS) in the UK produces a set of statistics on share ownership every two years. We provide information on this in Appendix I. So, in September 2015 we were informed that for the year 2014 some $53.7 \%$ of shares in UK listed companies were owned by foreign investors. The report issued in November 2017 (giving the profile up to December 2016) indicated that the percentage of foreign share ownership had increased to $53.9 \%$. That figure has risen constantly in

illuminating general discussion of the true nature of shareholding see M. Koutsias [2017] 28 ICCLR 217.

23. Macaura v Northern Assurance [1925] AC 619.

24 Theft of company assets by a company controller is thus possible - see Attorney General's Reference (No. 2 of 1982) [1984] QB 624.

25 Lakatamia Shipping Co Ltd v Su [2014] EWCA Civ 636, [2015] 1 WLR 291. The same thinking underpins $R v$ Boyle Transport (Northern Ireland) Ltd [2016] EWCA Crim 19.

26 There used to be a specific offence of personation under s. 84 of the Companies Act 1948 - i.e. falsely pretending to be a shareholder so as to vote or receive dividends. This was scrapped and such behaviour is now caught by general theft/fraud legislation. Under Company Law in Ireland (Companies Act 2014 s. 101), Gibraltar (Companies Act 2014 s. 158) and India (Companies Act 2013 s. 57) it remains a discrete offence. 
recent decades (from $31 \%$ in 1998 and less than $10 \%$ in the early 1960s), but one wonders whether Brexit might trigger a retreat in that pattern. The general policy of English law is not to discriminate against foreign shareholders (save in time of war); ${ }^{27}$ this right to equal treatment is enshrined in the G20/OECD Principles of Corporate Governance. ${ }^{28}$ But equally, it must be stressed that foreign shareholders are subject to the same obligations owed by local shareholders. ${ }^{29}$

These shareholders range from large institutional investors holding millions of shares in well-known public companies, to private investors with a few shares in a single company. Share ownership patterns vary from jurisdiction to jurisdiction. Institutional investors, in the wider sense of the term, hold about $25 \%$ of UK quoted shares. Private share ownership has been on the wane in the UK, with only $12.3 \%$ of shares in value being held by private investors in UK companies at December 2016 (compared to over $50 \%$ in the early 1960s), but in China it is a mainstream activity; hence the angst generated by the stock market crash in China in the summer of 2015. Shares in quoted companies held in multiple-ownership pooled accounts amount to some 59\% for the 2014 total and $62.5 \%$ of the 2016 overall figure.

The policy of English law has traditionally been to open up the possibility of share ownership to a wide range of groupings. Shares can be owned by all natural persons (including minors) and by artificial entities such as corporations. Local authorities may own shares in companies $^{30}$ and so may universities. ${ }^{31}$ One company can hold the shares of another company. ${ }^{32}$ This produces radical consequences and gives rise

27 Daimler v Continental Tyre and Rubber Co [1916] 2 AC 307.

28 These Principles were first developed in 1999, and the latest version was agreed in 2015 .

29 Re FH Lloyd Holdings plc [1985] BCLC 293. But see Winpar Holdings Ltd v Joseph Holt Group plc [2002] BCC 174 where the court recognised in practice that foreign shareholders in 'forbidden territories' were at some disadvantage.

30 Their power to do this is derived from s. 2 of the Local Government Act 2000 and s. 95 of the Local Government Act 2003. Some large ventures are in effect controlled by local authorities. The company running Manchester Airport has local authorities comprising nearly two-thirds of its shareholders.

31 So we have the phenomenon of spin off or spin out companies - often formed by joint ventures between universities and academics in the life sciences field. See generally S.A. Shane, Academic Entrepreneurship: University Spinoffs and Wealth Creation (2004) (Edward Elgar).

32 So under s. 323 of the Companies Act 2006 an investing corporate shareholder can appoint a representative to vote for it at shareholder meetings. 
to the parent/subsidiary phenomenon, which is at the heart of modern business operations. ${ }^{33}$ This phenomenon which results in the spreading of limited liability to a second level has never been fully evaluated by policymakers, but it is so embedded in the corporate law model that change is unlikely. This latitude is subject to one major restriction; a subsidiary ${ }^{34}$ generally cannot acquire the shares in a parent company. This particular curb is reiterated by s. 136 of the Companies Act 2006. That said, the 19th century precautionary rule ${ }^{35}$ that a company could not acquire its own shares has largely been swept away by liberalisation of share capital maintenance law.

Directors frequently own shares in the companies they manage. This facility opens up a range of incentivising options to provide a basis for executive remuneration. Indeed, the constitution of the company may require them to hold qualification shares; this was common in the past. The thinking here is that it will provide an incentive to improve managerial performance, but this requirement to hold shares is less commonly used these days. Where there is a share qualification requirement, failure to obtain said shares might affect the rights of directors to claim remuneration. ${ }^{36}$

There are no nationality or residence restrictions imposed upon would-be shareholders under English Law. We operate an open market and this has proved of great benefit to the City of London over the years. The ONS statistics show an increasing constituency of overseas investors in the shares of UK listed companies, with the 50\% threshold having been crossed a decade ago. Those overseas investors may range from private individuals to sovereign wealth funds (national investment funds set up by countries with huge petro dollar surpluses requiring safe but profitable berths). ${ }^{37}$

A state may acquire shares in a private enterprise. It can take control of a private business through a policy of nationalisation (see Appendix III for illustrations). There is however a danger to avoid here. If the state is simply

\footnotetext{
33 This phenomenon first appeared in the USA in the late 19th century.

34 There appears to be an exception for foreign subsidiaries - see Arab Bank $v$ Mercantile Holdings [1994] Ch 71.

35 See Trevor $v$ Whitworth (1887) 12 App Cas 409.

36 Craven-Ellis v Canons Ltd [1936] 2 KB 403. Though it may be that s. 160 of the Companies Act 2006 would preserve the validity of the director's acts vis-à-vis third parties.

37 The Norwegian SWF is the largest of these players. For an account of the investments made by SWFs see B. Gong, Understanding Institutional Shareholder Activism (2014) (Routledge) at 85-88.
} 
using this tactic to pump taxpayers' money into a failing enterprise this might offend against the 'market economy investor principle' (MEIP) ${ }^{38}$ under EU state aid law (see TFEU art 107). The fate of this rule in the future is unclear and will be subject to the final outcome of Brexit negotiations. The WTO has its own state aid (or subsidies) rules. These are much more flexible than their EU counterparts.

\subsection{HOW ARE SHARES CREATED?}

Shares do not grow on trees and do not materialise out of thin air. They must be created by an issuer. This can occur in a variety of ways. When a company is incorporated, initial members subscribe for its shares. At a later stage of the company's evolution fresh shares may be created to suit the capital (and strategic) needs of the company. The size of the share capital of a company has totemic significance. It may also serve as an anti-takeover device by making the company a more expensive target for a hostile bidder. The idea of a maximum authorised share capital ceiling (formerly prescribed by the Companies Act 1985) was not restated in the Companies Act 2006, though there is an obligation to register an up-to-date statement of capital (ss. 10 and 649). ${ }^{39}$ These issues will be considered further in Chapter 3 below.

\subsection{DEALING IN SHARES}

Shares, especially those in public companies, are designed to be freely transferable. Aspects of the law relating to share transfer will be reviewed in Chapter 4 below.

As to who actually executes transfers, we need to bear in mind the role of brokers. Their activities as intermediaries have opened up the share as an investment choice. Share registrars also come into play. This is increasingly the case in an era of intermediated securities.

38 For a discussion of this concept within state aid law see S. Cornella (2015) 22 Maas Jo of Euro and Compar Law 553. The principle was considered in the Court of Appeal in $R$ (on the application of Sky Blue Sports and Leisure Ltd) $v$ Coventry City Council [2016] EWCA Civ 453 and by the European General Court in Ciudad de La Luz (Joined Cases T319 and T321 of 2012) (unreported, 3 July 2014), where the General Court dismissed an annulment application in respect of a Commission decision to declare that illegal state aid had been granted.

39 See also Small Business, Enterprise and Employment Act 2015 s. 97. 
Shares in public companies need a capital market in which a transfer can occur. The nature of the market may vary - there are full markets and over the counter markets (which are increasingly important). On any given day hundreds of millions of shares change hands via these markets.

This market may play a secondary role in disciplining underperforming directors by exposing them to loss of office via shareholder revolt or takeover. The 'market for corporate control'40 is a well-known phenomenon to scholars of Corporate Law since the pioneering work of Henry Manne. ${ }^{41}$ According to this theory the market will encourage good performance by directors in managing the company's finances or else the shareholders will sell up to a new owner, via the free capital market, who will install fresh management with a view to improving returns to shareholders. This is an important theory but it loses some of its vigour in the context of shareholdings in private companies.

The FCA retains tight control over share dealings by operating under Part VI of the Financial Services and Markets Act 2000, a system known as official listing. It maintains an official list of recognised securities (s. 74 of the 2000 Act) and authorises the development of Listing Rules (s. 73A). We have noted that those who deal in regulated share activities must be authorised. There are strict rules on who may be authorised and on who may control an authorised person (see Part XII of the Financial Services and Markets Act 2000).

We should take note of the issue of global custodianship of shares global custodians look after both documented and dematerialised shares. This role will be considered in more depth in Chapter 4 .

\subsection{WHY REGULATE SHARES? THE LINK WITH PUBLIC POLICY}

Shares represent an item of private property and so the question inevitably arises as to why it is felt to be necessary to regulate them.

One reason lies in the development of welfarism. Shares are seen as products and, like all products, society now feels the need to protect purchasers (in this case investors). Share hawking by unlicensed door-todoor salesmen was banned in the UK in 1939.42 Any person dealing in shares must be authorised under the Financial Services and Markets Act

\footnotetext{
40 For discussion see C. Bradley (1990) 53 MLR 170.

41 Note in particular his piece in (1965) 73 Jo of Pol Econ 110.

42 On this area see H.L. Ooi (1993) 14 Co Law 208.
} 
2000 (as amended). ${ }^{43}$ Foreign boiler rooms are closed down typically by winding up the companies that operate them up in the public interest pursuant to s. $124 \mathrm{~A}$ of the Insolvency Act 1986.44 Cold calling is prohibited and this restriction has the seal of approval of the European Court of Justice, which has accepted the desire of Member States to promote integrity in their own investment markets. ${ }^{45}$ Most civilised systems of corporate law prohibit insider trading and the wider forms of market abuse such as market rigging. ${ }^{46}$ Attempts to artificially inflate the market price of quoted shares will be subject to serious sanction. ${ }^{47}$

Welfarism has its limits. Although shares may be financial products and those who buy shares enjoy protection of the Financial Conduct Authority, shares are not regarded as 'goods' for the purposes of the Sale of Goods Act 1979 or the Consumer Rights Act 2015. This is because shares are choses in action and are thus excluded from the category of goods by s. 61 of the Sale of Goods Act 1979. This is an old established

43 See the Financial Services and Markets Act 2000 s. 19. It is a criminal offence to contravene this - s. 23.

44 On winding up in the public interest in other cases where companies dealing in securities are deemed to pose a threat to the public see Re Walter $L$ Jacob Ltd (1989) 5 BCC 244, where one of the complaints made was that the company was not keeping track of share certificates relating to clients' investments. See also the discussion in Re UK-Euro Group plc [2007] 1 BCLC 812 where the allegations included claims that commissions paid to agents were not being disclosed and that the sums being raised from investors were not being put to their intended use.

45 In Alpine Investments BV v Minister van Financien (C 384/93) [1995] 2 CMLR 209 the European Court of Justice ruled that a ban on cold calling investors in other Member States did interfere with free movement of services but that interference was proportionate and justified by the need to protect local investment markets.

46 That is, ramping up share prices by false rumours and then selling up when the price has been artificially inflated. The US term for this is 'pump and dump'.

47 There are recorded instances of this happening. This was one of the devices employed by the late Robert Maxwell in the 1980s and early 1990s. At the height of the Guinness/Argyll takeover battle for Distillers in 1986 an illegal share support scheme was employed to prop up the price of a bidder's shares so as to make them more attractive to the target company's shareholders who were being enticed with a share exchange. This resulted in prosecutions and a DTI investigation. For the background story see N. Kochan and H. Pym, The Guinness Affair: Anatomy of a Scandal (1987) (Helm). 
exemption in English law. ${ }^{48}$ That said, a person who buys a share certificate as a collector's item might however argue that he has bought 'goods' and could claim the benefit of consumer protection legislation. A share certificate issued by a defunct company could hardly be viewed as a chose in action. This matter remains to be tested in the UK courts.

There is another fundamental reason why regulation over shares is prescribed. The answer lies in the connection with the economic attribute of limited liability which has been afforded to the shareholder. The decision to go for the limited liability model in 1855 was a public policy choice par excellence. We are talking about a form of 'regulatory taking'. Shares are not unique in this sense - all forms of private property are subject to some form of regulation for this reason.

Apart from the connection with the incidence of limited liability, the linkage with public policy can be explained by a variety of other considerations.

A business can be acquired by the process of share acquisition. This may trigger competition law concerns where an area of economic activity falls under concentrated control. EU Competition Law has long recognised that increasing control over a company by share acquisition may offend merger policy. ${ }^{49}$

The volume of share dealing is vital to the economic health of the City of London. Any action that may constrain the volume of share dealing requires careful thought. We have seen this concern at work in the debate over the so-called proposal for an EU Financial Transaction Tax, ${ }^{50}$ which is part of a wealth distribution strategy. This idea has attracted a mixed response on the Continent and is opposed by the UK. This is less likely

48 It can be traced back to s. 62 of the Sale of Goods Act 1893. Curiously this is not the position in India under the Sale of Goods Act 1930. But that differential is mitigated by virtue of the fact that shares do not become goods in India until actually allotted. Choses in action also fall outwith the protections offered by the Torts (Interference with Goods) Act 1977, as s. 14 makes clear.

49 See for example Europemballage Corp and Continental Can Co Inc v European Commission [1973] CMLR 199 (potential abuse of dominant position). The acquisition of a minority shareholding might give rise to a suspicion of an anti-competitive agreement - British American Tobacco and Reynolds Industries $v$ Commission (C142 and 156/84) [1988] 4 CMLR 24. See generally EU Merger Regulation 139/2004. For analysis of this scenario see P. Fotis and N. Zavgolis, The Competitive Effects of Minority Shareholdings (2016) (Bloomsbury). In the UK we have the Enterprise Act 2002 Part 3, as amended by the Enterprise and Regulatory Reform Act 2013 Part 4.

50 This proposed levy originated from an EU Commission proposal of 2011. 
to be a cause of concern in the future, though it has been superseded by other concerns linked to Brexit.

Legitimate concerns may arise from time to time in connection with foreign share ownership. Protectionism may rear its head. Many iconic UK companies have been taken over by foreign concerns (Cadbury's being a prime example). This was a factor in the abortive Astrazeneca bid by the US firm Pfizer in 2014. ${ }^{51}$ The problem is that public policy (and EU law) favours open capital markets.

Governmental policy may favour privatisation (that is the divesting of ownership of a business from state control). At the same time the state may wish to retain control over a privatised sector. This is where so-called golden shares make their appearance. These curiosities are discussed below in Chapters 2 and 4. Some background information on privatisation over time is to be found in Appendix IV.

The state has at its disposal a range of legislative tools to further public policy goals. These might include Company Law, Revenue Law and Exchange Control (which was abolished in the UK in October 1979). ${ }^{52}$ There is no doubt that the courts are aware of public policy considerations and these undoubtedly influence their decisions. ${ }^{53}$

As shares represent an important element of private wealth one can easily understand how a state might wish to regulate share ownership. The most obvious tool to achieve this is through taxation. In recent decades we have seen significant tax breaks being offered to those who invest in personal equity plans (PEPs), ${ }^{54}$ or latterly in shares via an individual savings account (ISA). Also, from the tax year 2016/17 the first $£ 5000$ of dividend income is tax free; this should encourage investment in shares by small-scale investors. There are also tax reliefs designed to support the financing of businesses, such as the Enterprise Relief from Capital Gains Tax. Shares may offer the opportunity to further government policy in other spheres; for example, in terms of encouraging employee participation in enterprise through employee share ownership. Again, tax breaks

51 For background on this bid, which was withdrawn by the US firm Pfizer, see Financial Times 26 May 2014.

52 Large-scale share issues in the UK used to require permission from the Capital Issues Committee which operated from 1939 to 1969 - this was linked to wartime controls on the productive use of capital.

53 This may provide an explanation for the decision of Harman $\mathrm{J}$ in $R e$ Scandinavian Bank plc [1987] BCLC 220. The former view was that UK shares had to be denominated in sterling - see Lord Wright in Adelaide Electric Supply Co Ltd v Prudential Assurance Co Ltd [1934] AC 122 at 150.

54 First introduced via the Finance Act 1986. 
and concessions from general restrictions in corporate law might be used to attain this goal. Tax concessions may encourage people to invest in ordinary shares to promote capital investment in unquoted companies witness the Enterprise Investment Scheme. ${ }^{55}$

\subsection{DENOMINATION OF SHARES}

The position in English Law in general (and supposedly ${ }^{56}$ in EU Law) is that every share that is issued must have a nominal or par value. This par value enables a number of rules on share capital maintenance to operate. Shares cannot be issued for below par value. ${ }^{57}$ On the other hand, it causes confusion amongst the general public in that the par value has nothing to do with the market value of the share. North American systems of corporate law do not maintain this tradition. This trend of scrapping par value has spread across the globe, and in the Isle of Man companies can issue no par value shares. ${ }^{58}$ Indeed, some national systems $^{59}$ of Corporate Law actually prohibit the placing of a nominal value on the face of shares. In the UK the Gedge Committee ${ }^{60}$ recommended abolition of the par requirement, which was famously characterised by Gower as a 'slur' on the face of UK Company Law. ${ }^{61}$ This recommendation was never implemented.

Although English Law continues to insist upon each share having a designated par value, it does not require such value to be denominated in sterling. Harman $\mathrm{J}$ broke the mould in this respect in UK Company Law with his radical decision in $R e$ Scandinavian Bank plc. ${ }^{62}$ This ruling,

55 There are curbs on the types of company and the types of share, Abingdon Health Ltd v HMRC [2016] UKFTT 800 (TC).

56 In fact it is clear that no par value shares are to be found in a number of EU states including France, Germany and Italy.

57 Ooregum Gold Mining Co of India v Roper [1892] AC 125. This rule cannot be circumvented by use of convertible debentures - Moseley $v$ Koffyfontein Mines Ltd [1904] 2 Ch 108.

58 See Isle of Man Companies Act 2006 s. 29.

59 For example, Canada (Canadian Business Corporations Act s. 24), Hong Kong (Companies Ordinance s. 135), New Zealand (Companies Act 1993, s. 38) and Malaysia (Companies Act 2016 s. 74).

60 1954, Cd 9112. The Cohen Committee in 1945 had resolved on maintaining the status quo - see Cmd 6659 para 18.

61 See (1956) 69 Harv L Rev 1382 at 1400.

62 [1987] BCLC 220. Harman J did qualify this by indicating that a plc must have a minimum of $£ 50 \mathrm{~K}$ designated in sterling, but even this insignificant 
which recognised the decline of sterling and the role now played by international capital, was in effect affirmed by s. 542(3) of the Companies Act 2006.

The Companies Act 2006 further advanced this flexibility by allowing companies to redenominate their shares already in circulation - see ss. 622-628. So, shares originally issued with a sterling denomination can be modified to having their nominal value converted to a different currency. There is little evidence on the extent to which this new opportunity to redenominate has been exploited.

Nominal values can in effect be changed by a process of share consolidation. ${ }^{63}$ This involves combining together a number of low denomination shares into fewer but higher denomination shares. It is permitted by s. 618 of the Companies Act 2006, which also permits the reverse process of share division. There may be sound economic and market reasons for undertaking these processes. For instance, certain institutional investors are required to invest in shares with higher denominations. Conversely, low denominations might prove to be more attractive to the stock market.

\subsection{SHARES AND THE WIDER SOCIO-ECONOMIC CONTEXT}

Shares, like all forms of investment, do not exist in a world of isolation. Their relative importance/attractiveness is inevitably linked to the underlying macro-economic climate. That environment encompasses current rates of taxation, prevailing interest rates for deposits and the relative attractiveness of other forms of investment (such as property). All of these factors affect the relative popularity of shares.

The obvious answer to the question as to which role is played by shares is that the share allows a person to invest a limited amount of capital in a venture with minimal risk. But that is not the whole story. Shares can fulfil other functions. So they can be used to regulate relationships within wider commercial organisations where the existence of the company is largely incidental.

qualification has been watered down by substituting a euro equivalent of $65 \mathrm{~K}-$ see The Companies (Authorised Minimum) Regulations 2008 (SI 2008/729). See generally N. Daubney and N. Cannon (1987) 6 Int Fin L Rev 7, and L. Thornton (1988) 9 Co Law 51.

63 Sometimes called reverse stock splitting. 
So, for example, in order to be a member of the Premier League a football club must own a share in the League. The holding of the share in this context is not an investment per se, but a precondition to membership. This is exemplified by Fulham FC (1987) Ltd v Richards. ${ }^{64}$ The intangible membership right is often the most prized asset of a club, frequently much more valuable than the football ground or even the players.

A similar situation arises with regard to estate management, particularly where the estate in question is a block of flats. ${ }^{65}$ It is a common requirement in such a scenario that individual flat owners must own a share in the estate management company. This scenario has the potential to generate share-related litigation. ${ }^{66}$

\subsection{SHAREHOLDERS AS MEMBERS}

There is an important distinction to be noted here. A person to whom shares have been transferred is designated a 'shareholder'. But that is an inchoate status - the critical designation is that of 'member'. A shareholder must be registered on the register of members to enjoy the full rights and obligations of a member of a company. This long-standing general principle was reasserted by Lord Collins in Farstad Supply A/S v Enviroco Ltd. ${ }^{67}$ Moreover, the person in question must have agreed to become a member; a formal contract is not required, but there must be evidence of assent. ${ }^{68}$ Where the term 'member' is used in legislation the presumption is that this means a current member, ${ }^{69}$ but that presumption may be displaced so as to encompass former members. ${ }^{70}$

This distinction can cause some difficulties where shares have been transferred by operation of law. This can arise on the death or bankruptcy of the member. This difficulty is often counteracted by providing an extended definition of a member. So, for example, the Insolvency Act 1986

64 [2011] EWCA Civ 855.

65 See the facts of Estmanco (Kilner House) Ltd $v$ GLC [1982] 1 WLR 2.

Note also Bratton Seymour Service Co Ltd v Oxborough [1992] BCC 471.

66 See for instance Chong v Alexander [2016] EWHC 735 (Ch).

67 [2011] UKSC 16 at para [39]. See also Re D'Nick Holdings plc (Eckerle v Wickeder Westfalenstahl) [2013] 3 WLR 1316 where Norris J held that indirect investors did not qualify as the holders of shares for the purposes of s. 98 .

68 Re Nuneaton Borough AFC [1989] BCLC 454.

69 See Lord Mance in Pearson v Primeo Fund [2017] UKPC 19 at para [29].

70 See Re Anglesea Colliery Co (1866) LR 1 Ch App 555, Re Consolidated Goldfields of New Zealand Ltd [1953] Ch 689, Re Compania de Electricidad de La Provincia de Buenos Aires [1980] Ch 146. 
s. 250 provides an extended definition of a member. Thus, a transferee can present a winding up petition. The meaning of 'member' may vary from one statutory provision to another. So, in Re Bowling and Welby's Con$\operatorname{tract}^{71}$ a narrow view was taken, with the court holding that it does not cover a trustee or personal representative. But, in Llewellyn $v$ Kasintoe Rubber Estates Ltd $^{72}$ a wide view was taken as to who might be viewed as a member in a scheme of reconstruction. Similarly, in Re Bayswater Trading Co $\operatorname{Ltd}^{73}$ a wide view was taken so as to enable a personal representative to be included, even if not named on the register of members.

The question of membership was further considered by the Court of Appeal in Randhawa v Turpin. ${ }^{74}$ The issue here was whether a company, which had remained on the register of members in spite of the fact that it had been dissolved, could still be regarded as a member of the company for the purposes of the unanimous assent rule. ${ }^{75}$ The Court of Appeal held that the appearance of this dissolved corporate shareholder on the register was decisive of the matter.

\subsection{THE NUMBERS' GAME}

Formerly, Company Law used minimum and maximum membership as a sort of regulatory control mechanism. So, it used to be the case that every company was required to have a minimum of two members. ${ }^{76}$ That ceiling on membership was enforced by the threat of personal liability for the sole remaining shareholder. ${ }^{77}$ It was only when the EEC introduced the idea of single member companies (originally via the 12th Company Law Harmonisation Directive $89 / 667 / \mathrm{EEC})^{78}$ that this principle was dropped in English Law. Originally, single member companies were only

\footnotetext{
71 [1895] 1 Ch 663.

72 [1914] 2 Ch 670.

73 [1970] 1 WLR 343. See also James v Buena Ventura Nitrate Grounds Syndicate [1896] 1 Ch 456 where the member's name was still on the register.

74 [2017] EWCA Civ 1201.

75 Sometimes called 'the Duomatic principle' after Re Duomatic Ltd [1969] 2 Ch 365. For discussion see D. Milman [2017] 46 CLWR 198.

76 Public companies needed seven members.

77 See the now repealed Companies Act 1985 s. 24 and Nisbet v Shepherd [1994] BCC 91.

78 See now EU Directive 2009/102. A Proposal exists to extend further the options for the incorporation of single member companies.
} 
permitted in the private company context, ${ }^{79}$ but when the Companies Act 2006 took effect that concession was made generally available (see ss. 7, 38 and 123).

Private companies were for many years subject to a cap of 50 members (excluding employee shareholders). ${ }^{80}$ That upper limit, which was meant to reflect the cosy nature 81 of private companies, was eventually dropped. There are now many large private companies with hundreds of shareholders.

We have moved away from classifying companies by shareholder size. Other criteria are now used for differentiation purposes, such as balance sheet total, turnover and number of employees. ${ }^{82}$

\subsection{SHAREHOLDERS AS COMPARED TO PARTNERS AND MEMBERS OF LLPS}

Clearly there is much in common when considering these economic participation relationships, but there are significant differences to take account of.

In a traditional partnership a partner's interest or 'share' is explained by an eclectic range of provisions in the Partnership Act 1890, including ss. 24, 31, 39 and 43.83 There is however no simple definition provided. The point to remember is that every partner has managerial participation rights unless the partnership deed curbs these. Quantifying a partnership 'share', which may be required on dissolution of partnership, is no easy matter. ${ }^{84}$

The distinction has been muddied since 2001 with the advent of the limited liability partnership (LLP) via the coming into force of the Limited Liability Partnerships Act 2000. Over the course of a decade the LLP has attracted some 50,000 registrations. The LLP model has also spread

79 See The Companies (Single Member Private Companies) Regulations 1992 (SI 1992/1699).

80 See Companies Act 1948 s. 28.

81 In one sense it mirrors the old upper limit of 20 members on partnerships as reflected in s. 434 of the Companies Act 1948 (a cap which was gradually eroded and then removed).

82 See for example Companies Act 2006 s. 382.

83 For recent discussion in the High Court in Ireland see Re Bloxham (in liquidation) [2017] IEHC 664, where there is discussion also of the concept of 'share' in a limited partnership.

84 See Ham v Ham [2013] EWCA Civ 1301 and the later proceedings in [2016] EWHC 1791 (Ch). 
globally. In recent times the UK courts have been called upon to analyse the nature of the interest which an LLP member enjoys in the LLP firm. Thus, in Reinhard $v$ Ondra LLP ${ }^{85}$ Warren J explained matters thus:

the 'share' of a member [of an LLP] is the totality of the contractual or statutory rights and obligations of that member which attach to his membership.

This characterisation has much in common with the company share, which is not surprising as the LLP was conceived as a corporate entity rather than a partnership structure conferring limited liability on its members.

\subsection{SHAREHOLDERS IN COMPANIES AS COMPARED TO MEMBERS IN MUTUAL ORGANISATIONS}

This is an important comparison to make. It was particularly relevant in the past when members of a mutual organisation (typically a building society) were offered financial inducements (usually in the form of free shares) to convert their position to that of a shareholder in a public company as part of a demutualisation process - for historic examples see Appendix III. Many members took up this inducement. A member of a mutual might be either a depositor or a borrower. Under Schedule 2 of the Building Societies Act 1986 (as amended by s. 2 of the Building Societies Act 1997) membership is restricted to shareholder members and borrowing members. This dichotomy is not reflected in Corporate Law. Demutualisation has extended to the stock exchanges themselves: the NYSE and the LSE both went down this road of switching from a mutual organisation to that of a company with its own shareholders in 1999.

\subsection{SHAREHOLDERS AND OTHER STAKEHOLDERS WITHIN A COMPANY}

When we think of those having a stake in a company we focus naturally upon shareholders who have invested in the company. The shareholder

85 [2015] EWHC $26(\mathrm{Ch})$ at paras [54]-[57]. For later proceedings in this litigation see [2015] EWHC 1869 (Ch) and [2015] EWHC 2943 (Ch). See also Hosking v Marathon Asset Management LLP [2016] EWHC 2418 (Ch) at paras [30]-[31] per Newey J. 
primacy perspective is but one manifestation of this obsession. But we must be careful not to blind ourselves to other contributors who have a financial stake in the company. We must be careful to consider the position of a shareholder compared to that of a creditor. There are importance differences in terms of rights. An investor who provides share capital is not a creditor of the company. Equally, we need to remind ourselves of the rights of those who supply labour to the company. Finally, the position of the state must be taken into account. All of these stakeholder groups are in effect recognised by s. 172 of the Companies Act 2006, but at the moment it is only shareholders who enjoy private law enforcement rights under Company Law.

\subsection{TYPES OF COMPANY}

The discussion so far has proceeded largely on the basis that the term company is monolithic and refuses to recognise diversity. Nothing could be further from the truth. There are many types of company and the differentiation can affect the regulation of shares issued by these various entities. ${ }^{86}$ So, we have public and private companies (see the Companies Act 2006 s. 4). There are companies limited by shares and by guarantee (typically a charitable company) (s. 5). Community Interest Companies appear on the UK corporate scene (s. 6). There are limited and unlimited companies (s. 3). Some companies are said to be 'small' (s. 382), whereas others count as 'medium sized' (s. 465). Companies may be classified as quoted. ${ }^{87}$ Others are said to be 'listed' or 'traded' (s. 360C). Historically there are still old joint stock companies (see ss. 1040 and 1041) plus UK registered companies (s. 1158) and unregistered companies (s. 1043). Add to this mix the possibility of a company being designated as an overseas company (s. 1004), an investment company (s. 833) $)^{88}$ or a dormant company (s. 1169) and the picture of serendipity becomes clear. This differentiation is largely the work of the legislature, but the courts have played their part. ${ }^{89}$ This diversity, which for the most

86 The best guide to what follows is provided by s. 1262 and Sched 8 of the Companies Act 2006 which maps out an index of defined expressions.

87 See Companies Act 2006 ss. 531, 385.

88 Not to be confused with open-ended investment companies - see Financial Services and Markets Act 2000 ss. 236 and 262.

89 In the late 19th century the private company was known to the courts, but it did not receive explicit legislative approval until 1907. The categorisation of 
part has increased with the passage of time, ${ }^{90}$ needs to be borne in mind in the following discussion. Where it becomes important an attempt will be made to highlight it.

\subsection{SHARES AND THE FACILITATION OF FRAUD ${ }^{91}$}

For any committed socialist, the concept of shares immediately raises suspicions. They would be seen as key parts of the capitalist toolkit and as devices under which personal liability for commercial decisions could be avoided by placing the artificial entity of the company between the shareholding entrepreneur and the outside world. Moreover, tradable shares can provide the means by which frauds are facilitated. One need look no further than the South Sea Bubble, which we note in Chapter 2 below. Having said that, attitudes to company frauds have evolved over the passage of time. ${ }^{92}$

False prospectuses provide an obvious opportunity to gull the public into parting with funds. Regulation in this field dates back to the 19th century. ${ }^{93}$ 'Boiler room' frauds, under which unregulated firms (often based abroad) engage in cold calling vulnerable persons, are particularly disreputable and are under constant scrutiny by the regulators. As intimated above, such firms may be wound up in the public interest pursuant to s. 124A of the Insolvency Act 1986.

Insider trading or market abuse are obvious examples of fraudulent activity, with the victim here not being the individual, but the integrity of the market. Insider dealing is now viewed as one aspect of the wider problem of market abuse. An extreme example of this phenomenon is provided by the recent case in Germany featuring the Borussia Dortmund

companies as close or as quasi-partnerships is entirely the work of judicial ingenuity.

90 Although the category of exempt companies was abolished in English Law in the Companies Act 1967.

91 For context see S. Wilson, The Origins of Modern Financial Crime (2014) (Routledge). See generally M. Gale, S. Gale and G. Scanlan (2001) 22 Co Law 98.

92 See the account by J. Taylor in (2011) 32 Co Law 291 of how attitudes changed in the 19 th century.

93 Compare the common law approach in Derry v Peek (1889) 14 App Cas 337. See M. Lobban (1996) 112 LQR 287, and for a general discussion of history and policy in the period note S. Wilson, Ch 17 in T.T. Arvind and J. Steele, Tort Law and The Legislature: Common Law, Statute and the Dynamics of Legal Change (2012) (Hart Publishing). 
football coach bombing, ${ }^{94}$ which was allegedly designed to depress the price of shares in a football club in order to enable the alleged perpetrator to exploit the device of a put option.

Another way in which shares can facilitate fraud is where a "man of straw' is allowed to buy into a company by borrowing from the company to fund the share purchase. Having thus gained a controlling stake, this 'investor' then conspires to asset strip the company to produce funds to repay his debt and hopefully make a profit through the whole exercise. This was recognised as a fraud in $1929^{95}$ and the financial assistance rules were introduced to combat it. These rules are discussed in Chapter 3 below.

Shares can also be used as prime instruments to facilitate artificial tax avoidance, which in modern morality discourse is seen as virtually the equivalent of fraud. The sad story of 'employee shares' (see Chapter 2 below) illustrates how a good idea can be distorted by game players simply in order to minimise tax burdens.

One of the more celebrated frauds recorded in history is that carried out by 'General Gregor MacGregor', a former military officer with experience in the independence wars in South America. This scam (which took place in England in the 1820s) involved no less than the creation of a fictitious state in Central America, 'the Principality of Poyais', and then selling investments in that non-existent country. Those investments took the form of government bonds, land certificates and to a lesser extent shares in companies set up to trade with Poyais, ${ }^{96}$ all of which proved to be worthless. The fraud was only uncovered when settlers returned from the supposed location to report that it was mosquito infested jungle. The tale is interesting enough to have inspired a book solely dedicated to its intricacies. ${ }^{97}$

\footnotetext{
94 See the account of this incident in The Times 22 April 2017.

95 See the Greene Committee (1926, Cm 2657) and Companies Act 1929 s. 45 .

96 The share fraud actually took place in France and some of the associates of the prime mover were convicted for that secondary element in the scam.

97 See David Sinclair, The Land that Never Was: Sir Gregor MacGregor and the Most Audacious Fraud in History (2004) (Da Capo) at 266 and 288 in particular.
} 